\title{
Books Received / Livres reçus
}

Aragona, Tullia d'. The Poems and Letters of Tullia d'Aragona and Others: A Bilingual Edition. Edited and translated by Julia L. Hairston. The Other Voice in Early Modern Europe: The Toronto Series 28. Toronto: Iter Inc. / Centre for Reformation and Renaissance Studies, 2014. Pp. xii, 352. ISBN 978-0-7727-2154-9 (paperback) \$39.95.

Asbach, Olaf and Peter Schröde, eds. The Ashgate Research Companion to the Thirty Years' War. Farnham, UK and Burlington, VT: Ashgate, 2014. Pp. xiv, 347. ISBN 978-1-4094-0629-7 (hardcover) £85.

Baschera, Luca, Bruce Gordon, and Christian Moser, eds. Following Zwingli: Applying the Past in Reformation Zurich. St. Andrews Studies in Reformation History. Farnham, UK and Burlington, VT: Ashgate, 2014. Pp. ix, 300. ISBN 978-0-7546-6796-4 (hardcover) \$134.95.

Blasucci, Luigi. Sulla struttura metrica del «Furioso» e altri studi ariosteschi. Quaderni di stilistica e metrica italiana 4. Florence: SISMEL / Edizioni del Galluzzo, 2014. Pp. viii, 198. ISBN 978-88-8450-536-1 (paperback) $€ 34$.

Britton, Dennis Austin. Becoming Christian: Race, Reformation, and Early Modern English Romance. New York: Fordham University Press, 2014. Pp. xi, $259+2$ ill. ISBN 978-0-8232-5714-0 (hardcover) \$55.

Bucer, Martin. De vera et falsa caenae dominicae administratione (1546). Edited by Nicholas Thompson. Studies in Medieval and Reformation Traditions 184. Leiden: Brill, 2014. Pp. xiv+320. ISBN 978-9-0042-7323-8 (hardcover) $€ 126 / 163$.

Carew, Richard. The Examination of Men's Wits. Edited by Rocío G. Sumillera. London: Modern Humanities Research Association, 2014. Pp. ix, 375. ISBN 978-1-78188-161-3 (paperback) \$44.99.

Carvajal y Mendoza, Luisa. The Life and Writings of Luisa de Carvajal y Mendoza. Edited and translated by Anne J. Cruz. The Other Voice in Early Modern Europe: The Toronto Series 29. Toronto: Iter Inc. / Centre for Reformation and Renaissance Studies, 2014. Pp. xiv, $369+4$ ill. ISBN 978-0-7727-2156-3 (paperback) \$39.95.

Cavallo, Jo Ann. The World Beyond Europe in the Romance Epics of Boiardo and Ariosto. Toronto: University of Toronto Press, 2013. Pp. xi, 377. ISBN 978-1-4426-4683-4 (hardcover) \$85.

Renaissance and Reformation / Renaissance et Réforme 37.3, Summer / été 2014 
Christiansen, Keith et al. Piero della Francesca: Personal Encounters. New York: The Metropolitan Museum of Art, 2013. Pp. 96 + 50 ill. ISBN 978-0-30019946-8 (paperback) \$19.95.

Deitz, Luc, Timothy Kircher, and Jonathan Reid, eds. Neo-Latin and the Humanities. Essays in Honour of Charles E. Fantazzi. Essay and Studies 32. Toronto: Centre for Reformation and Renaissance Studies, 2014. Pp. 289. ISBN 978-0-7727-2158-7 (paperback) \$34.95.

Du Bosc, Jacques. L'Honnête Femme: The Respectable Woman in Society and the New Collection of Letters and Responses by Contemporary Women. The Other Voice in Early Modern Europe: The Toronto Series 31. Toronto: Iter Inc. / Centre for Reformation and Renaissance Studies, 2014. Pp. Xv, 332. ISBN 978-0-7727-2160-0 (paperback) \$39.95.

Duggan, Christopher. A Concise History of Italy. Second edition. Cambridge, UK: Cambridge University Press, 2014. Pp. xxviii, $338+41$ ill, 6 maps. ISBN 978-0-521-74743-1 (paperback) \$28.95.

Dupuis, Margaret and Grace Tiffany, eds. Approaches to Teaching Shakespeare's Taming of the Shrew. New York: Modern Language Association of America, 2013. Pp. xii, 248. ISBN 978-1-60329-119-4 (paperback) \$19.75.

Engammare, Max et Elexandre Vanautgaerden (éds.) avec la collaboration de Franz Bierlaire. L'intime du droit à la Renaissance. Actes du cinquantenaire de la FISIER. Cahiers d'Humanisme et Renaissance 117. Genève : Librairie Droz, 2014. 544 p. ISBN 978-2-600-01729-9 (broché) \$102.

Erdmann, Ales, Alberto Govi, and Fabrizio Govi. Ars Epistolica: Communication in Sixteenth Century Western Europe: Epistolaries, Letter-Writing Manuals and Model Letter Books 1501-1600. With an introduction by Judith Rice Henderson. Luzern: Gilhofer \& Ranschburg GmbH / Modena: Libreria Alberto Govi di Fabrizio Govi Sas, 2014. Pp. xxv, 771. ISBN 978-3-03304329-9 (hardcover) €150.

Feigenbaum, Gail with Francesco Freddolini. Display of Art in the Roman Palace 1550-1750. Los Angeles: Getty Research Institute, 2014. Pp. xiv, $368+50$ colour and 118 b/w ill. ISBN 978-1-60606-298-2 (hardcover) \$75.

Ferrer, Véronique. Exercices de l'âme fidèle. La literature de piété en prose dans le milieu réformé francophone (1524-1685). Genève : Librairie Droz, 2014. 370 p. ISBN 978-2-600-01746-6 (broché) 61.61 €.

Flore, Jeanne. Tales and Trials of Love: A Bilingual Edition and Study. A Bilingual Edition and Study. Edited and translated by Kelly Digby Peebles. Poems 
translated by Marta Rijn Finch. The Other Voice in Early Modern Europe: The Toronto Series 33. Toronto: Iter Inc. / Centre for Reformation and Renaissance Studies, 2014. Pp. xiv, 342. ISBN 978-0-7727-2166-2 (paperback) $\$ 39.95$.

Fuchs, Barbara, Larissa Brewer-García, and Aaron J. Ilika, eds. and trans., "The Abencerraje" and "Ozmín and Daraja": Two Sixteenth-Century Novellas from Spain. Philadelphia: University of Pennsylvania Press, 2014. Pp. x, 139. ISBN 978-0-8122-4608-7 (hardcover) \$39.95.

Gambara, Veronica. Complete Poems: A Bilingual Edition. Edited and translated by Molly M. Martin and Paola Ugolini. Critical introduction by Molly M. Martin. The Other Voice in Early Modern Europe: The Toronto Series 34. Toronto: Iter Inc. / Centre for Reformation and Renaissance Studies, 2014. Pp. xiii, 168. ISBN 978-0-7727-2168-6 (paperback) \$39.95.

Garnier, Isabelle et Olivier Leplatre, éds. Impertinence générique et genres de l'impertinence (XVI ${ }^{e}-X V I I I^{e}$ siècles). Cahiers du Gadges, 10. Genève : Librairie Droz, 2012. 512 p. ISBN 978-2-36442-023-6 (broché) $28 €$.

Goodrich, Jaime. Faithful Translators: Authorship, Gender, and Religion in Early Modern England. Evanston, IL: Northwestern University Press, 2014. Pp. xi, 244. ISBN 978-0-8101-2938-2 (paperback). \$9.95.

Grisone, Federico. The Rules of Riding: An Edited Translation of the First Renaissance Treatise on Classical Horsemanship. Edited by Elizabeth MacKenzie Topbey, translated by Elizabeth MacKenzie Tobey and Federica Brunori Deigan. Medieval and Renaissance Texts and Studies 454. Tempe, AZ: ACMRS, 2014. Pp. xxii, 627. ISBN 978-0-86698-505-5 (hardcover) $\$ 75$.

Hall, Crystal. Galileo's Reading. Cambridge, UK: Cambridge University Press, 2013. Pp. 249. ISBN 978-1-107-04755-6 (hardcover) \$99.95.

Haywood, Eric. Fabulous Ireland / Ibernia Fabulosa: Imagining Ireland in Renaissance Italy. Oxford: Peter Lang, 2014. Pp. x, 293. ISBN 978-3-03431758-0 (paperback) \$70.95.

Hirschfeld, Heather. The End of Satisfaction: Drama and Repentance in the Age of Shakespeare. Ithaca: Cornell University Press, 2014. Pp. xii, 239. ISBN 978-0-8014-5274-1 (hardcover) \$55.

Houston, Chloë. The Renaissance Utopia: Dialogue, Travel and the Ideal Society. Farnham, UK and Burlington, VT: Ashgate, 2014. Pp. 198. ISBN 978-1-

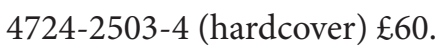


Kammerer, Elsa. Jean de Vauzelles et le creuset Lyonnais. Un humaniste catholique au service de Marguerite de Navarre entre France, Italie et Allemagne (1520-1550). Travaux d'Humanisme et Renaissance, 522. Genève : Droz, 2013. 522 p. ISBN 978-2-600-01647-6 (broché) \$86.40.

Lucioli, Francesco. Amore punito e disarmato. Parola e imagine da Petrarca all'Arcadia. Collana Studi e Ricerche 9. Rome: Sapienza Università Editrice, 2013. Pp. $348+41$ b/w and colour ill. ISBN 978-88-98533-09-1 (paperback) €22.

McCue Gill, Amyrose and Sarah Rolfe Prodan, eds. Friendship and Sociability in Premodern Europe: Contexts, Concepts, and Expressions. Essays and Studies 33. Toronto: Centre for Reformation and Renaissance Studies, 2014. Pp. $318+4$ ill. ISBN 978-0-7727-2170-4 (paperback) \$39.95.

Mellyn, Elizabeth W. Mad Tuscans and Their Families: A History of Mental Disorder in Early Modern Italy. Philadelphia: University of Pennsylvania Press, 2014. Pp. 290. ISBN 978-0-8122-4612-4 (hardcover) \$55.

Milstein, Joanna. The Gondi: Family Strategy and Survival in Early Modern France. Farnham, UK and Burlington, VT: Ashgate, 2014. Pp. 260. ISBN 978-1-4094-5473-1 (hardcover) $£ 63$.

Mounier, Pascale et Colette Nativel, éds. Copier et contrefaire. Faux et usage de faux. Actes du colloque organisé par R.H.R. et la S.F.D.E.S. Octobre 2009, Université Sorbonne. Paris : Honoré Champion, 2014. 491 p. ISBN 978-27453-2577-8 (broché) $75 €$.

Palfrey, Simon. Poor Tom: Living King Lear. Chicago: University of Chicago Press, 2014. Pp. 272. ISBN 978-0-226-15064-2 (hardcover) \$35.

Parr, Katherine. Complete Works and Correspondence. Edited by Janel Mueller. Chicago: University of Chicago Press, 2014. Pp. $645+2$ ill. ISBN 978-0226-21379-8 (paperback) \$50.

Perry, Nandra. Imitatio Christi: The Poetics of Piety in Early Modern England. Notre Dame, IN: University of Notre Dame Press, 2014. Pp. viii, 280. ISBN 978-0-268-03841-0 (paperback) \$32.

Prodan, Sarah Rolfe. Michelangelo's Christian Mysticism: Spirituality, Poetry, and Art in Sixteenth-Century Italy. New York: Cambridge University Press, 2014. Pp. xiii, 251 +15 ill. ISBN 978-1-107-04376-3 (hardcover) \$99.95.

Renaissance Humanism: An Anthology of Sources. Edited and translated, with an introduction, by Margaret L. King. Indianapolis: Hackett Publishing Company, 2014. Pp. xxiii, 352. ISBN 978-1-62466-111-2 (paperback) \$19. 
Rust, Jennifer R. The Body in Mystery: The Political Theology of the Corpus Mysticum in the Literature of Reformation England. Evanston, IL: Northwestern University Press, 2014. Pp. xx, 249. ISBN 978-0-81012931-3 (paperback) \$39.95.

Sponholz, Jesse and Gary K. Waite, eds. Exile and Religious Identity. Religious Cultures in the Early Modern World 18. London: Pickering \& Chatto, 2014. Pp. 288. ISBN 978-1-84893-457-3 (hardcover) $£ 60 / \$ 99$.

Sweetnam, Mark S. John Donne and Religious Authority in the Reformed English Church. Dublin: Four Courts Press, 2014. Pp. 203. ISBN 978-1-84682394-7 (hardcover) €58.50.

Targoff, Ramie. Posthumous Love: Eros and the Afterlife in Renaissance England. Chicago: University of Chicago Press, 2014. Pp. xiii, 243. ISBN 978-0226-78959-0 (hardcover) \$40.

Tyler, Margaret. Mirror of Princely Deeds and Knighthood. Edited by Joyce Boro. Tudor \& Stuart Translations 11. Cambridge, UK: Modern Humanities Research Association, 2014. Pp. ix, 279. ISBN 978-1-907322-16-7 (hardcover) \$44.99.

Walsham, Alexandra. Catholic Reformation in Protestant Britain. Catholic Christendom 1300-1700. Farnham, UK and Burlington, VT: Ashgate, 2014. Pp. 508. ISBN 978-0-7546-5723-1 (hardcover) $£ 80$.

Winn, Colett H., ed. Teaching French Women Writers of the Renaissance and Reformation. New York: Modern Language Association of America, 2011. Pp. vii, 431. ISBN 978-1-60329-090-6 (paperback) \$25.

Wolf, Anne Marie. Juan de Segovia and the Fight for Peace: Christians and Muslims in the Fifteenth Century. History, Languages, and Cultures of the Spanish and Portuguese Worlds. Notre Dame, IN: University of Notre Dame Press, 2014. Pp. xi, 375. ISBN 978-0-268-04425-1 (paperback) \$45. Wyatt, Michael, ed. The Cambridge Companion to the Italian Renaissance. Cambridge, UK: Cambridge University Press, 2014. Pp. xxvii, $442+24$ ill. ISBN 978-0-521-69946-4 (paperback) \$30.95.

Zabarella, Jacopo. On Methods. On Regressus. Translated by John P. McCaskey. The I Tatti Renaissance Library 58-59. 2 vols. Pp. xxvi, 323, 470. ISBN 978-0-674-72479-2, 978-0-674-72480-8 (hardcover) \$29.95 each. 
